\title{
EXPLORING THE ADVANCEMENT AND ROLES OF ISLAMIC MICROFINANCE INSTITUTIONS IN MICROENTERPRISE DEVELOPMENT IN NIGERIA
}

\author{
Umar Aliyu Maishanu ${ }^{1,2}$ and A.K Siti-Nabiha1, * \\ 1 Graduate school of Business, Universiti Sains Malaysia, Penang, Malaysia \\ 2 Abdu Gusau Polytechnic Talata Mafara, Zamafara State
}

\begin{abstract}
This paper discusses the advancement and roles of microfinance institutions, specifically Islamic microfinance institutions in microenterprise development in Nigeria. Microfinance institutions play a key role in financial inclusion and microenterprise development, especially in developing countries. The key aim of microfinance initiatives is to eradicate poverty by providing access to a wide range of financial products and services for those who are financially excluded. The emergence of microfinance in Nigeria appears to be promising, as these institutions support Nigerians of average or poor means by improving their living conditions. However, the nature and conditions of the schemes do not satisfy the sensitivities and requirements of a substantial number of people including poor Muslims who need funding but are unable to take advantage of conventional microfinance services, as loan conditions are seen as being contradictory to Islamic teachings. Islamic microfinance, therefore, can alleviate poverty through the development of microenterprises.
\end{abstract}

\author{
ARTICLE HISTORY \\ Received: 3-6-2020 \\ Accepted: 1-9-2020

\section{KEYWORDS} \\ Islamic Microfinance, \\ Micro Enterprise, \\ Entrepreneurial \\ Development, \\ Nigeria
}

\section{INTRODUCTION}

Good economic growth cannot be realised without a well-focused policy that increases access to production factors, particularly credit, for poor and low-income people. Enterprise and entrepreneurship form the basis for economic growth and development in every country, but sadly, poor people have difficulties in accessing credit from commercial banks to set up small- or medium-sized enterprises (Olu, 2009; Taiwo et al., 2016). Microfinance concerns providing financial services to vulnerable people, who are excluded by mainstream financial institutions. Microfinance provides a wide range of services including credit, investments, insurance, etc. It is also becoming apparent that small and microenterprises have little access to traditional financial institutions and need a variety of financial products (Khan, 2020; Mathurin \& Zaka, 2012; Rock, Otero, \& Saltzman, 1998). Consequently, microfinance is a valuable means in funding entrepreneurship and microenterprises, contributing to job creation and the eradication of poverty among the poor who are not seen by commercial banks as bankable customers (Kanayo \& Nancy, 2013).

However, many potential microfinance customers in Nigeria particularly Muslims, have rejected traditional microfinance products due to their failure to adhere to Islamic values, as a result of high fixed-rate charges and unethical credit facilities which are against their faith (Central Bank of Nigeria [CBN], 2016; Dogarawa, 2009; Hussaini, 2017). In 2011, the framework policy and guidelines for microfinance were revised to accommodate non-interest (Islamic) microfinance institutions. The new structure which includes mainstream financial institutions and MFIs offers the establishment of Islamic MFIs on the basis of either full Islamic MFIs, or a subset or window within traditional MFIs (Al-ameen, 2016; Dogarawa, 2011; Rano, 2012).

The implementation of non-interest microfinance programmes is projected to bring into the official sector those individuals and microenterprises who are not prepared to patronise conventional microfinance institutions based on religious and cultural principles. This also helps the socially productive poor who patronise these institutions, alleviating poverty and improving their standard of living (CBN, 2016; Khalfa, 2015; Obaidullah, 2008; Abdul Rahman, 2010). Hence, microenterprises' access to financing enables their growth and sustainability. The presence and role of microenterprises in enhancing the economic growth of many countries in Asia is starting to be appreciated in Africa including Nigeria, where the growth of the economy continues to be enhanced from the micro-levels (Brau et al., 2015). Thus, Islamic microfinance institutions can play a significant role in enabling the development of microenterprises by providing access to financing and other services. Therefore, the main purpose of this paper is to discuss the advancement and roles of Islamic microfinance institutions in microenterprise development in Nigeria.

The paper has the following structure. The next part discusses the programmes established by the Nigerian government to develop microenterprises in the country. The subsequent sections provide a discussion of microfinance in Nigeria and the role of IMFIs in microenterprise development. 


\section{The Government Programs for Microenterprises Development in Nigeria}

The federal and state governments of Nigeria have adopted many initiatives and policies to promote microenterprises and business operations in Nigeria. Notable programmes include the Agricultural Credit Guarantee Scheme (ACGS) in 1973, Rural Banking Programme in 1977 (providing sectoral credit and distributing concessional rates of interest), the Nigerian Agricultural and Co-operative Bank Limited (NACB) in 1972, the implementation of the Nigerian Enterprises Promotion Decree (NEPD) in 1972 (which was revised in 1977), the Small and Medium Enterprises Development Agency of Nigeria (SMEDAN) 2003, and the National Economic Reconstruction Funds (NERFUND) 1989. The Nigerian Agricultural Insurance Corporation (NAIC), the People's Bank of Nigeria (PBN) 1989, and the Family Economic Advancement Program (FEAP) represent other avenues in Nigeria that promote entrepreneurial and microenterprise developments. The Nigerian government merged the NACB with the PBN and the FEAP in 2000 to create the Nigerian Agricultural Cooperative and Rural Development (NACRDB) to increase financial support for the agricultural industry. The National Poverty Eradication Programme (NAPEP) was also launched to provide financial services to microenterprises for the purposes of poverty reduction and entrepreneurial development (Anyawu, 2003; CBN, 2005; Osunde \& Mayowa, 2012).

Such attempts have been made as microenterprises contribute to poverty reduction by generating new jobs or increasing the number of existing enterprises. In addition, microenterprises often raise social capital by developing new markets, new products, new technology, new structural forms, new employment, using local raw materials, and delivering net improvements in real productivity (Ifeoma et al., 2018; Rasak, 2012; Samson, 2013).

Almost all these initiatives have achieved little progress in ensuring broad access to sustainable microfinance, which is a crucial tool of growth and poverty reduction, given the numerous efforts made by the government to formulate different policies that enable microenterprise and business development to eliminate poverty. The failure of these policies and institutions to have the desired effect on the growth of entrepreneurs and microenterprises has been attributed to different factors, including weak policy execution, financial exclusion, vast unserved market conditions, and corrupt leadership (Adejumo \& Olaoye, 2012; Ilemona et al., 2013; Kanayo \& Nancy., 2013; Rasak, 2012).

Due to the failure of previously adopted microenterprise and business finance policies, the Central Bank of Nigeria - the apex bank for the supervision and policy-making of financial institutions in Nigeria - adopted microfinancing as a major funding source for entrepreneurship and microenterprises in Nigeria (CBN, 2005; Osunde \& Mayowa, 2012). The Microfinance Policy was introduced in 2005 to provide microfinance both to small businesses and microenterprises, to empower low-income groups in Nigeria, and to meet financing needs. (CBN, 2005; Kanayo \& Nancy., 2013).

\section{Microfinance in Nigeria}

Microfinance pertains mostly to the provision of credit and savings facilities to financially excluded poor individuals, and to small businesses and microenterprises (Ben Abdelkader \& Mansouri, 2019; Mor, 2013; Onakoya \& Onakoya, 2013; Rokhman, 2013). Thus, microfinance has been recognised as one of the world's most important developmental policies (Ahlin \& Jiang, 2005).

In December 2005, the Central Bank of Nigeria (CBN) developed a microfinance policy framework to increase access to the financial services necessary to extend and upgrade the operations of microenterprises and low-income families, in order that they could contribute to rapid economic growth. Without enhancing access to production factors (particularly financial services) in this segment of the economy, no inclusive growth can be attained. Therefore, this bold initiative is still valid. The CBN reviewed the policy in 2011, five years following the formulation of the microfinance policy to address the experiences gained global changes, and the future prospects for small-scale enterprises in Nigeria (Abiola, 2011; Dogarawa, 2009; 2011; Hussaini, 2017; Kanayo \& Nancy, 2013; Onakoya \& Onakoya, 2013).

The objective of the 2005 Microfinance Policy was to create a regional microfinance system for Nigeria that would promote a viable and long-term distribution of diversified microfinance services to poor and low-income communities, which had limited access to (or were excluded from) financial services. Service delivery to small, medium, and microbusinesses could be improved via microfinance institutions. The policy also created a microfinance bank platform, improved the CBN's regulatory oversight of money stability and liquidity management, and provided an adequate tracking machine for Nigerian microfinance partner development activities (Abiola, 2012; CBN, 2005).

The microfinance system helps poor people to diversify and increase their sources of income, moving them out of poverty. Diversification makes it easier to address external impacts (Charles et al., 2011). In addition, this develops microenterprises, as they can secure credit on more favourable terms from microfinance banks (MFBs) and other microfinance institutions (MFIs) (Abiola, 2012; Mahat \& Zannah, 2017). The growth of the microenterprise sector is vital, as this sector is positioned to create jobs, create wealth, reduce poverty, and sustain economic growth and development. Microenterprises often help to sustain economic development through the output of a growing number of small-scale enterprises, which may grow to become larger firms. Despite the steps taken by the CBN to enable microfinance banks in both urban and rural areas to expand their facilities to the poor, many rural citizens remain unbanked. Thus, the less privileged in Nigeria are still excluded financially from the banking cycle (Ene \& Inemesit, 2015; Yakubu et al., 2018).

Despite the perceived contribution of MFIs, many Nigerians are still largely excluded from financial services, as clearly highlighted by the findings of the study on Enhancing Financial Innovation and Access (EFinA, 2018). The research findings, as illustrated in Figure 1, revealed that $36.8 \%$ of Nigerians (36.6 million adults) were excluded from 
financial services. The study showed that $48.6 \%$ of Nigerians were backed by established financial institutions (formal), while $14.6 \%$ were primarily funded by the informal market. The survey also revealed that Nigeria, in terms of financial exclusion, lagged behind South Africa (7\%), Rwanda (11\%), Kenya (17.4\%), Uganda (22\%), Tanzania (28\%), and Cameroon (36\%) (EFInA, 2018).

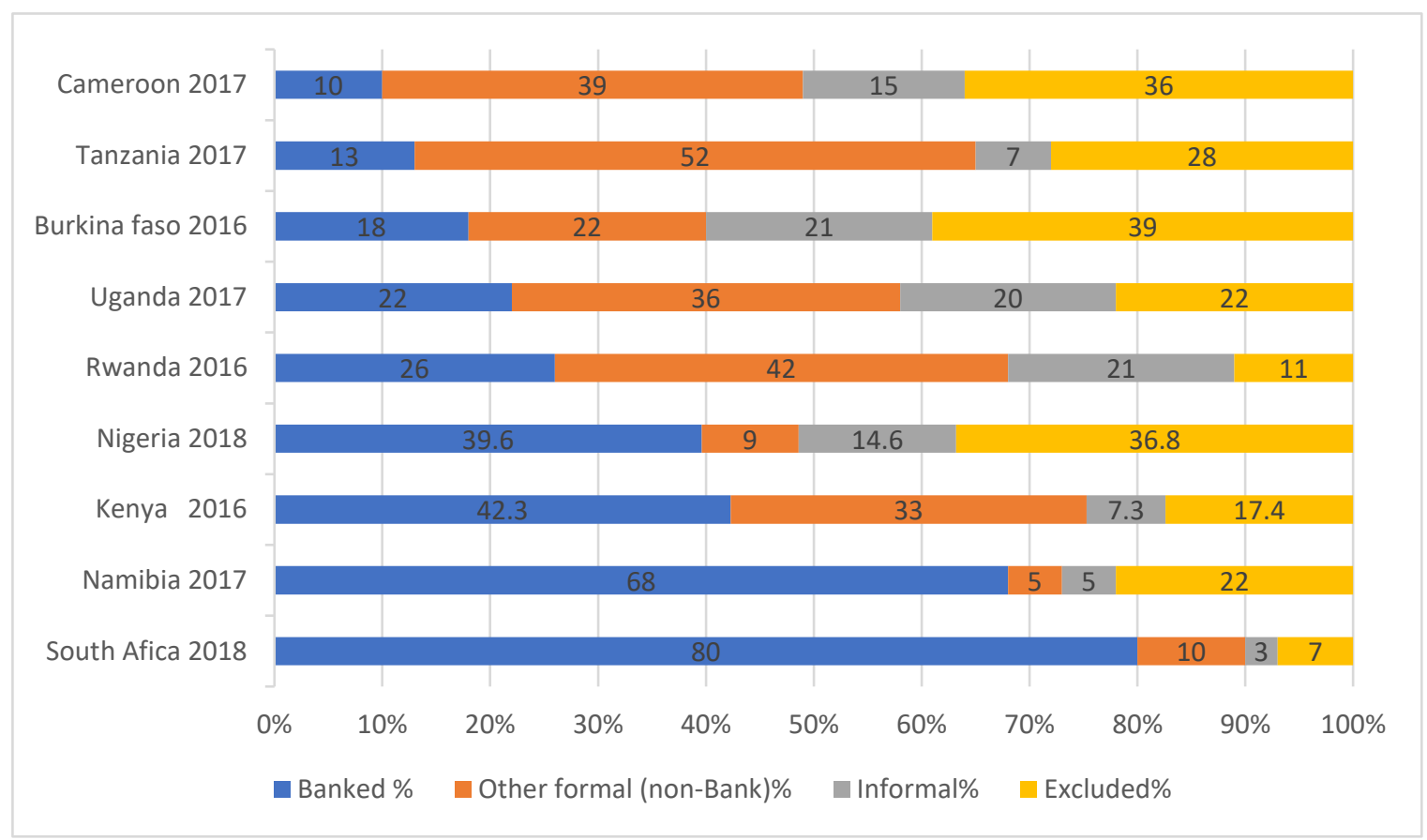

Figure 1. Proportion of financially excluded adults in some African countries

\section{Source:- (EFInA, 2018) Access to financial service in Nigeria survey}

Such low rates of financial exclusion are due to several factors. Even though the emergence of microfinance seems promising on the basis that these institutions are encouraging Nigerians of average or poor means to improve their standard of living through entrepreneurship, the nature and conditions of the microfinance schemes do not satisfy the sensitivities and requirements of a substantial group of people who would otherwise have been eligible for grants and loans in Nigeria. Due to perceived non-compliance with the Muslim faith (representing the majority of the population), there has been consciousness and desire among Nigerian Muslims to have access to a sharia-compliant microfinance institution (Dahinu \& Zubair, 2008; Dogarawa, 2011; Mohammed \& Hasan, 2009; Yakubu et al., 2018). Centred on these considerations, major Muslims voiced the desire for the implementation of an Islamic microfinance system as an alternative that can ensure the provision of financial and other services for them.

\section{The Development of Islamic Microfinance Institutions in Nigeria}

Islamic microfinance represents the provision of microfinance services based on and regulated by Islamic financial principles, thus avoiding interest, uncertainty, and speculation in activities (Rano, 2012). The Islamic financial system's most widely recognised aspect is the strict prohibition of the giving or receiving of fixed, pre-determined financial transaction return values (Dogarawa, 2011; Karim et al., 2008). Within the Islamic finance framework, money should be utilised to create real economic value and only a return on investment in sharia-allowable commercial activities can be earned. Therefore, as an alternative to 'riba', the profit and loss sharing (PLS) arrangements are held as an ideal mode of financing in Islamic microfinance (Alaro \& Alalubosa, 2019; Antonio, 2011).

As a result of the numerous calls by the majority of the Muslim population in Nigeria to have a sharia-compliant financial institution - which would serve as a bridge for poverty alleviation, microenterprise, and entrepreneurial development - the CBN claimed that reform of the policy had led to initiatives for non-interest (Islamic) financial institutions (NIFIs), considering lessons from the realistic application of conventional microfinance over five years. This is due to the global economic trends and the projected future for small business growth in Nigeria (Central Bank of Nigeria, 2011; Rano, 2012).

Therefore, the updated $2011 \mathrm{CBN}$ guidelines are aimed, inter alia, at providing the public with an alternative microfinancial banking structure focused on the principle of profit and loss sharing rather than interest payments. The adoption of this principle is expected to lead to wider and stronger competition between MFBs which could reduce business costs in the long term. The new banking system introduced by the CBN and the licensing of some non-interest financial institutions (NIFIs) further required the development and issuance of operating guidelines for the NIMFB (CBN, 2011; Momodu, 2013). The implementation of non-interest microfinance banking services will lead to citizens, societies, and businesses in the formal field refusing to patronise conventional MFBs based on religious, ethical, and cultural convictions. This will also help those economically active poor people who patronise those institutions in sustainable 
ways, alleviating poverty, addressing long-term inequalities, increasing income potential, and enhancing their overall welfare (CBN, 2016).

The size of the Muslim community is one aspect that may affect the need for Islamic microfinance in Nigeria. The last census of Nigeria showed that $55 \%$ of the population of the country were Muslim. The number of Muslims is thus projected to be 77 million. These people represent a major target for providers of financial services, as such people are likely to participate in one or more economic activities. Some Muslims' avoidance of conventional microfinance in Nigeria for the protection of their faith is another factor that shows the demand for Islamic microfinance. Poverty alleviation measures will neither have the desired result nor be successful without reaching all (or at least most) disadvantaged citizens. The lack of understanding of these particular religious factors therefore contributes to the failure of governmental and non-governmental organisations to effectively fight poverty (Khan, 2008).

These potentially excluded groups include poor Muslims who require funding but are unable to take advantage of conventional microfinance services because of the loan conditions such as the charging of fixed interest rates, which is seen as contradictory to Islamic teachings. Against this background, there have been calls for sharia-compliant microfinance institutions in Nigeria. As a result, the Central Bank of Nigeria revised its guidelines to contain the NIFIs which are sharia-compliant (CBN, 2016; UBN, 2019). Such reluctance to engage with conventional microfinance has also impacted the development of Muslim microenterprises.

Consequently, there is a tremendous need for financial services and MFIs, and Islamic microfinancing has a leading role to play. The Islamic microfinance industry of Nigeria is promising (Dahinu \& Zubair, 2008). The key consideration in the accomplishment of IMFIs' goals is that most people in Nigeria are Muslim and it is the most populated Muslim nation in Africa. This potential offers an opportunity to introduce and implement micro-investments that match the Muslim system of belief (Muhammad \& Arifzakaullah, 2013).

\section{IMFIs' Potential in Microenterprise Development and Poverty Eradication}

Since its emergence, the Islamic microfinance institution sector has realised diversified growth and multiple impacts. This is seen as a major trend in the development cycle, especially in the sense of globalisation with subsidies, grant-based programmes, and schemes losing their significance (Hassan, 2014). The position of Islamic microfinance is based more on poverty reduction among poor people and household income improvement through microenterprise participation. From a general standpoint, Islamic microfinance is a process of social inter-mediation and the building of social capital. The process of social inter-mediation is an investment that is made for the development of both human resources and institutional capital, allowing marginalised groups to become self-reliant and preparing them to engage in formal financial inter-mediation (Khan, 2008; Rano, 2012).

Mansori et al. (2015) postulated that Islamic financial principles and microfinance are key elements in the fastgrowing Islamic financial industry. The Islamic financial values apply not only to the financial needs of poor people but also to the social principles of underprivileged people. Although Islamic microfinance is in its early stages, it will encourage Muslims to accept the financial services provided by microfinancing institutions by offering financial products that comply with Islamic financial principles and will fulfil the requirements of Muslim microenterprises.

Thus, even though IMFIs have the same aims and challenges as conventional MFIs - as they strive for financially sustainable development and the empowerment of the poor - Dogarawa (2009) suggested that Islamic microfinance, arguably, could help to correct the shortcomings of conventional microfinance as it focuses on achieving social justice and addressing the issues of poverty and entrepreneurial development of the poor while disallowing exploitation through the charging of high-interest rates. This is further strengthened by the fact that 'adl' (social justice) and 'ihsan' (benevolence) are the theological foundations of the Islamic financial system. In this regard, Islamic finance contains social and equity components along with conventional financing practices that eventually favour the section of the population that is excluded, assisting the growth of its economic activities. The IMFIs' primary role is to expand economic opportunities and finance to the poor which is regarded as an effective solution in delivering poverty reduction and other economic benefits (Copestake et al., 2002; Dieter et al., 2006; Seibel, 2007).

The Islamic solution to poverty alleviation with microfinance underlines the need for a dual solution: a zakat and awqaf-based welfare initiative for the destitute, elderly and 'unbankable', and a microfinance wealth generation programme. Many of the values implicit in the Islamic solution include exposure to the system for the poorest of the poor, diligent evaluation of the financial wellbeing of the poor, empathic research, emphasis on investment and beneficiary participation, and turning the beneficiary's unproductive assets into income-generating assets by valuation (based on market discovery via auctioning) (Dogarawa, 2009; Abdul Rahman, 2010).

In order to enhance financial inclusion, poverty eradication, and sustainable economic growth and development, IMFIs present a variety of products for microenterprise development. Islamic microfinance products assume that human capabilities are diverse in the face of opportunities. The financing products consist of the following:

I. Musharaka

II. Mudarabah

III. Qardhul hasan

IV. Murabaha

V. Ijara

VI. Wadiah

VII. Other products such as Ijarah Muntahiya Bittmalik (lease to purchase), Wakala (procurement), Sarf (money 
exchange), and Hiwala (money transfer).

The types of products offered by IMFIs with their mode of operation and utilisation are shown in Table 2 . The mechanism for Islamic microfinance is very inclusive, so it is available for people of various means who are usually denied access to financial services through conventional channels (Mansori et al., 2015; Muhammad \& Arifzakaullah, 2013; Rahman, 2010).

Islamic microfinance institutions can provide various financing schemes, as shown in Table 2, to entrepreneurs who require small start-up capital and have no business experience. The IMFIs will only be allowed to charge a service fee. The term of repayment will be on an installment basis for an agreed period. The scheme is also relevant for microentrepreneurs who require immediate cash and who hold good potential to make a full settlement. Here, the microfinance institution will bear the credit risk and they need to choose the appropriate technique to ensure that repayments are made as agreed (Hassan, 2014; Mansori et al., 2015; Mohieldin et al., 2011; Muhammad \& Arifzakaullah, 2013).

Table 1: Instruments of finance in Islamic microfinance

\begin{tabular}{|c|c|c|c|}
\hline Product & Meaning & Mode of operation & Utilisation \\
\hline Musharaka & Joint venture & $\begin{array}{l}\text { An agreement in which all parties have agreed to } \\
\text { contribute labour and capital and share benefits, } \\
\text { based on the pre-agreed ratio. However, the loss is } \\
\text { dependent on the amount of money contributed. }\end{array}$ & $\begin{array}{l}\text { Can be used in small } \\
\text { production projects and } \\
\text { capital financing, } \\
\text { microenterprise \& } \\
\text { SMEs set-ups }\end{array}$ \\
\hline Mudaraba & Partnership & $\begin{array}{l}\text { This a partnership form whereby one partner } \\
\text { provides another partner with capital for } \\
\text { investment. The investment comes from the first } \\
\text { partner, named rabbul maal, and is managed by the } \\
\text { second partner, mudarib. If the manager (mudarib) } \\
\text { fails to act or split, benefits are shared in } \\
\text { accordance with the agreed mutual ratio while the } \\
\text { loss is borne by the fund provider (rabbul maal). }\end{array}$ & Investment \\
\hline Qardl- Hassan & Micro-credit & $\begin{array}{l}\text { This is credit extended on a goodwill basis by } \\
\text { Islamic banks to microenterprises and individuals, } \\
\text { and the debtor is only required to repay the amount } \\
\text { borrowed. It is the public's social responsibility to } \\
\text { the banks. }\end{array}$ & $\begin{array}{ll}\text { Benevolence loan, } \\
\text { emergency loan, } \\
\text { student, maternity, etc. }\end{array}$ \\
\hline Murabaha & $\begin{array}{l}\text { Mark-up } \\
\text { sales }\end{array}$ & $\begin{array}{l}\text { A contract for sale that consists of purchase on } \\
\text { behalf of a consumer of a product based on cost- } \\
\text { plus profits by the bank. The bank shows the } \\
\text { purchaser's full expense and profit margin. }\end{array}$ & $\begin{array}{l}\text { Financing asset or } \\
\text { working capital inputs }\end{array}$ \\
\hline Ijara & Leasing & $\begin{array}{l}\text { The client leases a product from a financier for a } \\
\text { predetermined cost. The finance institution retains } \\
\text { ownership of the asset and is responsible for its } \\
\text { maintenance. }\end{array}$ & $\begin{array}{l}\text { Small production unit } \\
\text { lease, auto financing, } \\
\text { equipment financing }\end{array}$ \\
\hline Wadia & $\begin{array}{l}\text { Micro- } \\
\text { savings }\end{array}$ & $\begin{array}{l}\text { Transfers of money by zakat and Sadaqat, and } \\
\text { insurance through the takaful concept. }\end{array}$ & $\begin{array}{l}\text { Current and savings } \\
\text { accounts }\end{array}$ \\
\hline
\end{tabular}

The financial services provided by MFIs are important for microenterprises, assisting in achieving the aim of job creation for those who are economically disadvantaged, new business formation, and livelihood improvement. Notwithstanding, financial services alone are not adequate to continuously boost clients' livelihoods and enhance microenterprises' sustainability (Al-shami et al., 2014).

There are two crucial interrelated reasons for the operation of socially responsible Islamic financial institutions: their function as a financial institution requires them both to fulfil a reciprocal religious obligation and to set a model as a financial intermediary (Farook, 2008). Islamic microfinance institutions should be able to significantly improve the performance of entrepreneurs and microenterprises through their financing mechanism. From this viewpoint, several elements of entrepreneurship and microenterprise growth may be compatible with IMFIs' broader goals. Both systems advocate value creation and risk sharing, and the belief that poor people should be involved in such activities. The disbursement of collateral-free loans and participatory funding at a very simple level is an example of how IMFIs and entrepreneurship have a common interest (Adamu, 2015). In a related development, the central practice in IMFIs is helping to reduce poverty, and promoting social justice and fair distribution of wealth to society. Thus, IMFIs need to mobilise with efforts to change the collective mindset of poor Nigerians of reliance on welfare assistance, empowering them to become more self-reliant. Therefore, the objective of Islamic finance needs to be shifted from the business mode to an emphasis on social benefits, and from merely focusing on the provision of financing to the development of nonfinancial services, including entrepreneurial development and character building. In doing so, IMFIs' role in microenterprise formation and sustainability is crucial. 
However, given that the majority of Nigerians are Muslims, and living below the poverty line despite the presence of different microfinance institutions, Islamic microfinance has a significant role in assisting those who are deprived of access to financial services in the development of their economic entrepreneurial activities. IMFIs also play a crucial role in ensuring the growth of microenterprises which are excluded from accessing the financing services of conventional commercial banks.

\section{CONCLUSION}

The Nigerian government has established policies and programmes to alleviate poverty and support microenterprise and entrepreneurial activities. Sadly, there has been limited success in ensuring broad access to sustainable microcredits, a critical instrument for growth and poverty reduction, in most of these programmes. This is due to poor policy implementation, financial exclusion, the existence of a huge unserved market, corruption, and bad governance, and such programmes and institutions have not produced the desired impact. In recent years, microfinance has become a key tool that assists many 'unbankable' members of society to escape poverty and promotes economic growth in neglected parts of the world. To this end, the Nigerian government launched its microfinance policy, regulatory framework, and supervisory framework through its Apex Bank (CBN) on 15 December 2005 with a view to meeting the financial needs of low-income people and developing their microenterprises.

Notwithstanding the adoption of the microfinance policy, a substantial number of Nigerians remain excluded from financial services due to the services provided not being aligned with their religious principles. Thus, in response to calls made for the provision of sharia-compliant microfinance, the CBN revised its microfinance policy in 2011 to cater to non-interest (Islamic) financial institutions (NIFIs) in order to promote financial inclusion without any part of society being excluded. The introduction of Islamic microfinance institutions is expected to bring into the formal sector those individuals, communities, and businesses that are reluctant to patronise conventional MFIs based on either religious, ethical, or cultural beliefs. Thus, Islamic microfinancing has great potential and can be used as a tool for the development of entrepreneurship and microenterprises in Nigeria, due to the different services it offers and the role it plays in the development of the economy. As IMFIs is relatively new in Nigeria, they are being implemented and used as mechanisms to expand economic and social development among the poorest people in the country, contributing to the formation, growth, and sustainability of microenterprises in Nigeria.

\section{REFERENCES}

Abiola, B. (2011). Impact Analysis of Microfinance in Nigeria. International Journal of Economics and Finance, 3(4), $217-225$. https://doi.org/10.5539/ijef.v3n4p217

Abiola, B. (2012). Effects of Microfinance on Micro and Small Enterprises (MSEs) Growth in Nigeria. Asian Economic and Financial Review, 2(1990), 12-30.

Adamu, I. Y. (2015). Analysis of perceived contribution of Islamic banking towards entrepreneurship development in Gombe state , Nigeria. International Conference on Social Science Research, 694-705.

Adejumo, D. G., \& Olaoye, J. A. (2012). Roles and Problems of Small - Scale Business Development Programmes in Nigeria. International Journal of Business and Management Studies, 2(Jan-march 2012), 76-83.

Ahlin, C., \& Jiang, N. (2005). Can micro-credit bring development? In Working Paper No. 05-W19 (Vol. 86, Issue 1). https://doi.org/10.1016/j.jdeveco.2007.08.002

Al-ameen, A. (2016). Implementing Islamic microfinance in Nigeria : a matter of equity and social justice. Journal Of Sustainable Devevelopment, Law \& Policy, 7(2), 212-246.

Al-shami, S. S., Majid, I. B. A., Rashid, N. A., \& Hamid, M. S. R. B. A. (2014). Conceptual Framework: The Role of Microfinance on the Wellbeing of Poor People Cases Studies from Malaysia and Yemen. Asian Social Science;, 10(1), $230-242$. https://doi.org/10.5539/ass.v10n1p230

Alaro, A. A., \& Alalubosa, A. H. (2019). Potential of Sharī' ah compliant microfinance in alleviating poverty in Nigeria: A lesson from Bangladesh. International Journal of Islamic and Middle Eastern Finance and Management, 12(1), 115-129. https://doi.org/10.1108/IMEFM-01-2017-0021

Antonio, M. S. (2011). IIslamic microfinance initiatives to enhance small and medium enterprises in Indonesia from historical overview to contemporary situation. Journal of Indonesian Islam; , 5(2), 313-334.

Ben Abdelkader, I., \& Mansouri, F. (2019). Performance of microfinance institutions in the MENA region: a comparative analysis. International Journal of Social Economics, 46(1), 47-65. https://doi.org/10.1108/IJSE-06-2017-0242

Brau, J. C., Cardell, S. N., \& Woodworth, W. P. (2015). Does Microfinance Fill the Funding Gap for Microentrepreneurs? A Conceptual Analysis of Entrepreneurship Seeding in Impoverished Nations. International Business Research, 8(5), 30-42. https://doi.org/10.5539/ibr.v8n5p30

C. M. Anyawu. (2003). The role of central bank of Nigeria in enterprises financing. In Seminar on Small and medium industries equity investments.

CBN. (2005). Microfinance policy, regulatory and supervisory framework for Nigeria (Issue 2009).

CBN. (2016). Guidelines on the regulation and supervision of non-interest (Islamic) microfinance banks in Nigeria. In Exposure draft Guidelines on the regulations and supervision of Non intersest (Islamic) microfinance bank in Nigeria. https://doi.org/10.1201/9781315157078-4

Central Bank of Nigeria. (2011). Microfinance policy framework for Nigeria revised. In Microfinance policy framework for Nigeria revised. https://www.cbn.gov.ng/cashless/

Charles, J. A., James, K., \& Hamed, B. A. (2011). Impact of Microfinance on Poverty Alleviation in Nigeria: An Empirical Investigation. European Journal of Humanities and Social Sciences, 2(1), 97-111.

Copestake, J., Johnson, S., \& Wright, K. (2002). Impact Assessment of Microfinance: Towards a New Protocol for Collection and 
Analysis of Qualitative Data (Vol. 44, Issue 7).

Dahinu, M. A., \& Zubair, H. (2008). Microfinance in Nigeria and the prospects of introducing an Islamic version in the light of selected muslim countries. Munich Personal RePEc Archive, 13(1), 155-174.

Dieter, H., Agung, D., \& Wahyu. (2006). Islamic Microfinance in Indonesia.

Dogarawa, A. B. (2009). Framework for an Effective Islamic Microfinance in Northern Nigeria. In SSRN Electronic Journal. https://doi.org/10.2139/ssrn.1624748

Dogarawa, A. B. (2011). Financial Inclusion in Nigeria and the Prospects and Challenges of Islamic Microfinance Banks. Enhancing Islamic Financial Services for Microenterprises, October.

Dusuki, A. W. (2008). Lifting Barriers in Financing the Small and Poor Entrepreneurs: Lesson From Group-Based Lending Scheme and Ibn Khaldun's Social Solidarity. Islamic Finance for Micro And Medium Enterprise, February.

EFInA. (2018). EFInA Access to Financial Services in Nigeria 2018 Survey. www,efina.org.ng

Ene, E. E., \& Inemesit, U. A. (2015). Impact of Microfinancein Promoting Financial Inclusion in. Journal of Business Theory and Practice, 3(2), 139-158.

Farook, S. (2008). Social Responsibility for Islamic Financial Institutions : Laying Down A Framework. Journal of Islamic Economics, Banking and Finance, 4(1), 61-82.

Hassan, A. (2014). The challenge in poverty alleviation: Role of Islamic microfinance and social capital. Humanomics, 30(1), 76-90. https://doi.org/10.1108/H-10-2013-0068

Hussaini, M. (2017). Islamic Micro Finance Bank: An Alternative Tool for Poverty Alleviation in Northern Nigeria. Islamic Economic Studies, 1, 59-70.

Ifeoma, A. R., Purity, N.-O., \& Yusuf, A. E. (2018). Effect of Entrepreneurship Development on Poverty Alleviation inEffect of Entrepreneurship Development on Poverty Alleviation in Nigeria. Journal of Business and Management (IOSR-JBM), 20(2), 80-87. https://doi.org/10.9790/487X-2002108087

Ilemona, A., Akoji, O., \& Matthew, A. (2013). Alleviating Poverty through the Use of Entrepreneurship Skill Acquisition in. Aceh International Journal of Social Sciences, 2(June), 1-10.

Kanayo, O., Jumare, F., \& Nancy, S. (2013). Challenges of Microfinance Access in Nigeria: Implications for Entrepreneurship Development. Mediterranean Journal of Social Sciences, 4(6), 611-618. https://doi.org/10.5901/mjss.2013.v4n6p611

Karim, N., Tarazi, M., \& Reiile, X. (2008). Islamic Microfinance: An Emerging Market Niche. In CGAP (Vol. 49, Issue March).

Khalifa, M. A. (2015). Integrating Zakah, Awqaf and Islamic Microfinance for Poverty Alleviation: Three Models Of Islamic Micro Finance

(Vols.

1435-19) https://www.researchgate.net/profile/Khalifa_Hassanain/publication/315804070_Integrating_Zakah_Awqaf_and_Islamic_Mic rofinance_for_Poverty_Alleviation_Three_Models_Of_Islamic_Micro_Finance_IRTI_Working_Paper_Series_Islamic_Econo mics_and_Finance_Research_Di

Khan, A. A. (2008). Islamic Microfinance theory,policy and practice. In Ajaz Ahmed Khan (Issue February, pp. 1-74). Islamic Relief worldwide, 19 Rea street Soutth Birmingham, B5 6LB, United Kingdom. https://doi.org/10.5040/9781472920379.0039

Khan, B. (2020). Microfinance Banks and its Impacts on Small and Medium Scale Enterprises in Nigeria. International Scientific Journal, 141(February), 115-131.

Mahat, F., \& Zannah, M. (2017). The Role of Microfinance Bank on the SMEs Performance in Nigeria. Governance and Sustainability of Global Business Economics Global, Smedan 2014.

Mansori, S., Kim, C. S., \& Safari, M. (2015). A Shariah Perspective Review on Islamic Microfinance The Predictive Effect of Positive Emotion on the Individual Work Performance In Banking Industry In Malaysia View project Intrapreneurial Behavior and individual characteristics View project A Shariah P. Asian Social Science, 11(9). https://doi.org/10.5539/ass.v11n9p

Matthurin, F., \& Ratsimalahelo Zaka, Z. (2012). Regulation and supervision of microfinance institutions: an example of cooperative credit. Munich Personal RePEc Archive, 39581.

Mohammed, A. D., \& Hasan, Z. (2009). Microfinance in Nigeria and the prospects of introducing its Islamic version there in the light of selected Muslim countries' experience. 1-18.

Mohieldin, M., Iqbal, Z., Rostom, A., \& Fu, X. (2011). The Role of Islamic Finance in Enhancing Financial Inclusion in OIC Countries. 8th International Conference on Islamic Economics and Finance, 1-57.

Momodu, D. (2013). Legal Framework for Islamic Banking and Finance in Nigeria. Electronic Journal of Islamic and Middle Eastern Law, 1, 160-170.

Mor, S. (2013). Microfinance and microentrepreneurship (S. Mor (ed.)). Published by Vista International Publishing House and printed at Himanshu Printers, Maujpur, Delhi-110 053.

Muhammad, A., \& Arifzakaullah, M. (2013). Applicability of Islamic Micro-Investment Model in Kano State, Nigeria: Empirical Evidence. Australian Journal of Basic and Applied Sciences, 7(4), 535-542.

Olu, O. (2009). Impact of microfinance on entrepreneurial development: the case of Nigeria. The International Conference on Administration and Business, 536-545. https://doi.org/10.30845/ijbss.v9n9p7

Onakoya, A. B., \& Onakoya, A. O. (2013). Islamic microfinance as a poverty alleviation tool: Expectations from Ogun State, Nigeria. Scholarly Journal of Business Administration, 3(2), 36-43.

Osunde, C., \& Mayowa, A. G. (2012). Microfinance and entrepreneurial development in Nigeria. Jorind, 10(3), 405-410.

Rahman, A. R. A. (2010). Islamic microfinance: An ethical alternative to poverty alleviation. Humanomics, 26(4), $284-295$. https://doi.org/10.1108/08288661011090884

Rano, S. U. (2012). Islamic banking and finance in Nigeria: issues, challenges and opportunities. Munich Personal RePEc Archive, 42573, 1-18.

Rasak, B. (2012). Small and Medium Scale Enterprises ( SMEs ): A panacea for Economic Growth in Nigeria. Journal of Management and Corporate Governance, 4(6), 83-98.

Rock, R., Otero, M., \& Saltzman, S. (1998). Principles and Practices of Microfinance Governance. Microenterprise Best Practices, 58(October), 1-45.

Rokhman, W. (2013). The Effect of Islamic Microfinance on Poverty Alleviation: Study in Indonesia Economic. Journal of Economics and Business, 11(2), 21-30.

Samson, A. Y. (2013). Microfinance Bank as a Catalyst for Entrepreneurship Development in Nigeria : Evidence from Ogun State. 4(12), 286-303. 
Seibel, H. D. (2007). slamic Microfinance in Indonesia: The Challenge of Institutional Diversity, Regulation and Supervision. A Symposium, April, 1-19.

Taiwo, J. N., Yewande, O. A., Edwin, A. M., \& Benson, K. N. (2016). The role of microfinance institutions in financing small businesses. Journal of Internet Banking and Commerce, 21(1), 1-20.

UBN. (2019). Union bank of Nigerai 2019 Annual report.

Yakubu, S. M., Haruna, M. A., \& Mohammed, A. I. (2018). Strategies for the Acceptability of Islamic Micro Finance Institutions in Nigeria. Journal of Economics and Finance, 9(6), 71-76. https://doi.org/10.9790/5933-0906027176

\section{ACKNOWLEDGEMENT}

The authors would like to express their gratitude and appreciation to the Malaysian Ministry of Education for the funding of this research through the Fundamental Research Grant Scheme (FRGS): Grant No. 203.PPAMC.6711633.

\section{AUTHORS' BIOGRAPHY}

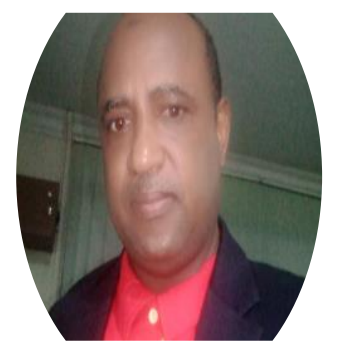

\section{Umar Aliyu Maishanu}

Umar Aliyu Maishanu is a PhD student at the Graduate School of Business, University Sains Malaysia, and a Principal lecturer at the Department of Business Administration, Abdu Gusau Polytechnic Talata Mafara, Zamfara State Nigeria. His research interest is business administration and management, specifically small business management, entrepreneurship and managerial economics

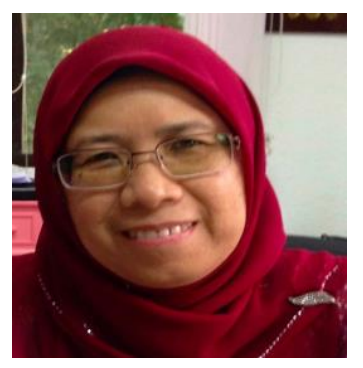

\section{Prof. Dr. A.K. Siti-Nabiha}

A.K. Siti-Nabiha is a Professor at the Graduate School of Business, Universiti Sains Malaysia. Her research interest is in the area of management accounting, specifically on issues related to accounting and organizational change, performance measurement, and systems of accountability and sustainability control systems in both the public and private sectors. 